\title{
Grazing intensity changed the activities of nitrogen assimilation related enzymes in desert Steppe Plants
}

\author{
Aimin Zhu', Haili Liu', Yuehua Wang ${ }^{1}$, Hailian Sun² and Guodong Han ${ }^{1 *}$
}

\begin{abstract}
Background: Nitrogen, as a limiting factor for net primary productivity in grassland ecosystems, is an important link in material cycles in grassland ecosystems. However, the nitrogen assimilation efficiency and mechanisms of grassland plants under grazing disturbance are still unclear. This study investigated Stipa breviflora desert steppe which had been grazed for 17 years and sampled the root system and leaf of the constructive species Stipa breviflora during the peak growing season under no grazing, light grazing, moderate grazing and heavy grazing treatments. The activities of enzymes related to nitrogen assimilation in roots and leaves were measured.

Results: Compared with no grazing, light grazing and moderate grazing significantly increased the activities of nitrate reductase (NR), glutamine synthetase (GS), glutamic oxaloacetic transaminase (GOT) and glutamic pyruvate transaminase (GPT) in leaves, and GS, GOT and GPT in roots of Stipa breviflora, while heavy grazing significantly decreased the activities of GS in leaves and NR in roots of Stipa breviflora. NR, GOT and GPT activities in leaves and roots of Stipa breviflora were positively correlated with nitrogen content, soluble protein, free amino acid and nitrate content.

Conclusions: Grazing disturbance changed the activities of nitrogen assimilation related enzymes of grassland plants, and emphasized that light grazing and moderate grazing were beneficial for nitrogen assimilation by grassland plants. Therefore, establishing appropriate stocking rates is of great significance for material flows in this grassland ecosystem and for the stability and sustainable utilization of grassland resources.
\end{abstract}

Keywords: Grazing, Stipa breviflora, Nitrogen assimilation, Enzyme activity

\section{Introduction}

Grazing is considered to be an important measure in grassland management. However, with the intensification of human activities, grazing disturbance in grasslands has become a concern [1, 2], and livestock grazing management remains very important for future

\footnotetext{
* Correspondence: hanguodong@imau.edu.cn

${ }^{1}$ College of Grassland, Resources and Environment, Key Laboratory of Grassland Resources of the Ministry of Education of Chian, Key Laboratory of Forage Cultivation, Processing and Higher Efficient Utilization of the Ministry of Agriculture and Rural Affaires of China, Inner Mongolia Key Laboratory of Grassland Management and Utilization, Inner Mongolia Agricultural University, 010019 Hohhot, China

Full list of author information is available at the end of the article
}

grassland protection [3]. Previous studies have shown that grazing affects grassland ecosystems mainly by changing plant and soil properties [4-6]. Desert grassland accounts for $39 \%$ of the grassland in Inner Mongolia [7], and long-term overgrazing has exacerbated grassland degradation in recent years, causing decreases in vegetation coverage, biodiversity and productivity [8]. Therefore, it is very important to understand how grazing management affects grassland ecosystems, especially in desert grasslands. Kotanen et al. [9] have shown that grazing can lead to decreases in nutrient content and leaf area of plants, thus affecting plant photosynthesis. Many previous studies have reported

C The Author(s). 2021 Open Access This article is licensed under a Creative Commons Attribution 4.0 International License, which permits use, sharing, adaptation, distribution and reproduction in any medium or format, as long as you give appropriate credit to the original author(s) and the source, provide a link to the Creative Commons licence, and indicate if changes were made. The images or other third party material in this article are included in the article's Creative Commons licence, unless indicated otherwise in a credit line to the material. If material is not included in the article's Creative Commons licence and your intended use is not permitted by statutory regulation or exceeds the permitted use, you will need to obtain permission directly from the copyright holder. To view a copy of this licence, visit http://creativecommons.org/licenses/by/4.0/ The Creative Commons Public Domain Dedication waiver (http://creativecommons.org/publicdomain/zero/1.0/) applies to the data made available in this article, unless otherwise stated in a credit line to the data. 
effects of grazing on nitrogen uptake and utilization of plants [10-12], but these studies have mainly focused on the level of nitrogen stoichiometry, and relatively few studies have focused on the mechanisms through which grazing affects nitrogen assimilation by plants.

Nitrogen is one of the essential elements for plant growth. Nitrogen assimilation refers to the process by which plants absorb nitrogen from the environment and synthesize nitrogen-containing organic compounds such as amino acids and proteins, a process in which many enzymes participate (Fig. 1). Inorganic nitrogen sources (ammonium salt and nitrate) in soil are the main nitrogen sources of plants. Although most plants can absorb $\mathrm{NH}_{4}{ }^{+}, \mathrm{NO}_{3}{ }^{-}$is the main nitrogen source for plants. The plants mainly rely on the cortex cells of the root to absorb nitrate from the rhizosphere soil. The leaves of plants can also absorb nitrate, but the amount of nitrate absorption is smaller than root absorption. In the process of nitrate assimilation, $\mathrm{NO}_{3}{ }^{-}$is reduced to $\mathrm{NH}_{4}{ }^{+}$by nitrate reductase and nitrite reductase [13], and then assimilated to glutamic acid and glutamine by glutamic acid synthase $[14,15]$. After that, other amino acids or nitrogenous compounds are formed under the action of transaminase. Glutamine synthetase (GS) and glutamic acid synthetase (GOGAT) are two important enzymes involved in catalysis during the glutamic acid synthetase cycle. The two important enzymes involved in the catalysis in the process of ammonia transfer are glutamic pyruvate transaminase (GPT) and glutamic oxaloacetic transaminase (GOT) $[16,17]$. Research on the mechanisms of plant nitrogen assimilation is relatively mature, and has mainly been conducted on wheat, rice, corn, soybean and other major crops [1820]. However, there are few studies on the mechanism of plant nitrogen assimilation in grazing grassland.

The soil of Stipa breviflora desert steppe is poor and the natural conditions are harsh. Species competition caused by grazing is also reflected in competition for nutrient resources $[7,21]$. In order to adapt to the environment, species gradually form external morphological characteristics and internal physiological adaptation strategies [22, 23]. The plant material selected in this study was Stipa breviflora, which is a constructive species in desert steppe. The population characteristics and morphological characteristics of S. breviflora change greatly under long-term grazing at different grazing intensities. For example, with increasing grazing intensity, individuals of $S$. breviflora undergo dwarfing, as leaves and plant clusters become shorter and aboveground biomass decreases, although the importance value increases with increasing grazing intensity and relative coverage and density also increase significantly [24]. Smith [25] and Li et al. [26] have come to similar conclusions in other grazing grassland studies. Previous studies showed that the total nitrogen content in plant roots and

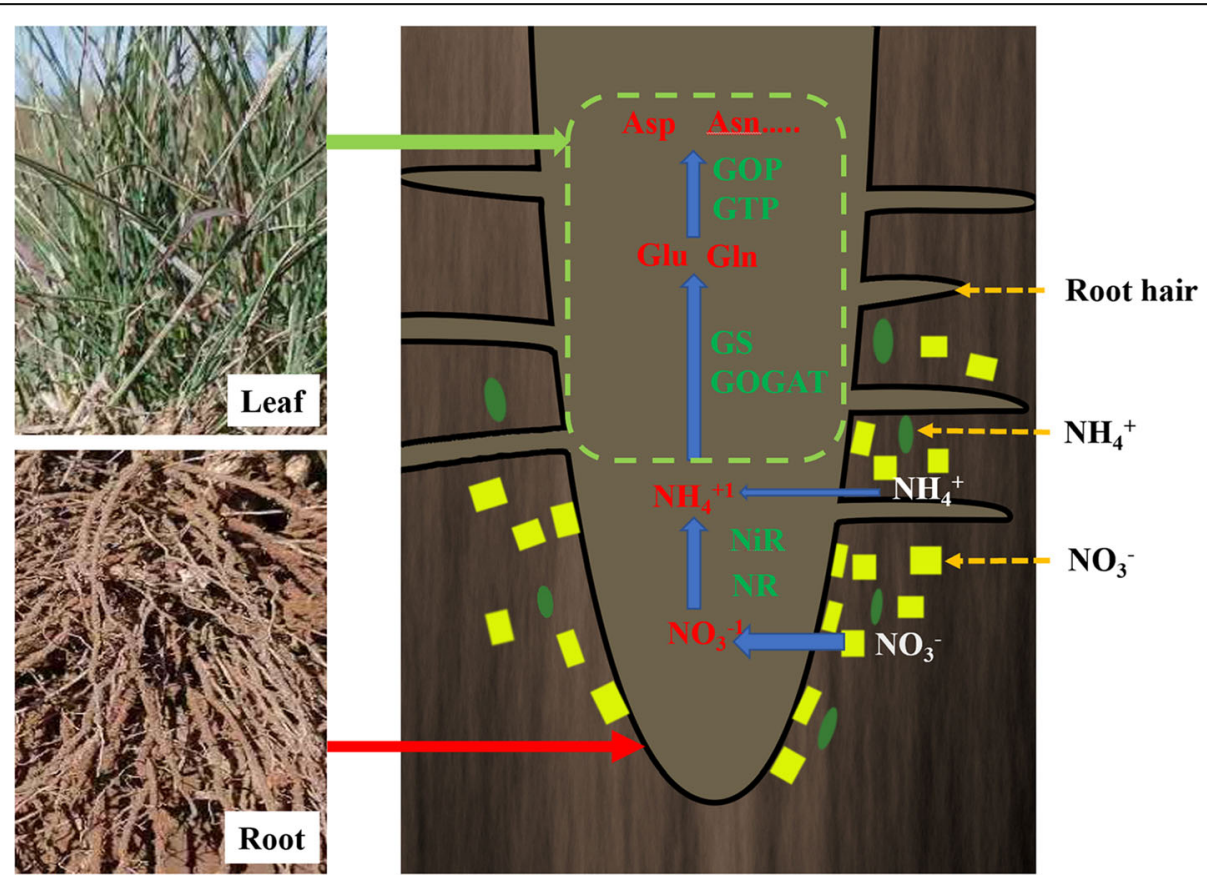

Fig. 1 Schematic diagram of plant nitrogen absorption and nitrogen assimilation process. The picture on the left shows the roots and leaves of plants, and the picture on the right shows the process of plant roots absorbing $\mathrm{No}_{3}{ }^{-}$and $\mathrm{NH}_{4}{ }^{+}$in soil and nitrogen assimilation catalyzed by enzymes. NR: nitrate reductase; NiR: nitrite reductase; GS: glutamine synthetase; GOGAT: glutamic acid synthetase; GOT: Glutamic oxaloacetic transaminase; GPT: glutamic pyruvate transaminase; Glu: glutamate; Gln: glutamine; Asp: Aspartic; Asn: Asparagines 
leaves changed significantly under different grazing treatments $[7,27,28]$.

However, it is not clear whether the changes in total nitrogen content in roots and leaves of S. breviflora under different grazing intensities are related to changes in the enzyme activities involved in nitrogen assimilation. Therefore, we proposed two scientific hypotheses: (1) Different grazing intensities change the activities of nitrogen assimilation related enzymes in leaves and roots of $S$. breviflora, which is consistent with the moderate disturbance hypothesis (i.e., the activities of nitrogen assimilation related enzymes in leaves and roots of $S$. breviflora would be higher under moderate grazing intensities). (2) The contents of nitrogen and nitrogen compounds in leaves and roots of S. breviflora are closely related to the activities of enzymes related to nitrogen assimilation, and show a significant positive correlation. In order to test these hypotheses, we sampled the constructive species S. breviflora in desert steppe experimental plots with 17 years grazing history in the peak growing season of 2020, and measured and analyzed the related indicators. This study can contribute to understanding of the patterns and mechanisms of nutrient absorption and utilization of grassland plants, and also provide technical and theoretical guidance for the rational and sustainable utilization of grazed grassland.

\section{Methods}

\section{Plant materials and sources}

S. breviflora samples were collected in long-term grazing experimental plots, which is located in Siziwang Banner $\left(41^{\circ} 47^{\prime} 17^{\prime \prime} \mathrm{N}, 111^{\circ} 53^{\prime} 46^{\prime}\right.$ " E, elevation $1450 \mathrm{~m}$ ) at the comprehensive experiment and demonstration center of Inner Mongolia Academy of Agriculture and Animal Husbandry Sciences, China. S. breviflora is a wild constructive species in desert grassland that is widely distributed in the western part of Inner Mongolia Autonomous Region, and it is not an endangered plant species. The manager of Inner Mongolia Academy of Agriculture and Animal Husbandry Sciences approved us to collect samples of $S$. breviflora, and identified the samples and supervised the sampling process. The annual average precipitation of desert steppe is $280 \mathrm{~mm}$, more than $80 \%$ of which is concentrated in May to September, and the average annual temperature is $3.4{ }^{\circ} \mathrm{C}$. The soil type is light chestnut soil.

\section{Experimental design}

The experiment was a randomized block experiment. The experimental plots covered about $50 \mathrm{hm}^{2}$ of natural grassland, and had been enclosed for 17 years (20042020). The plots were divided into three blocks. Each block had four treatment plots (no grazing, light grazing, moderate grazing and heavy grazing). Each treatment was repeated three times, and the area of each experimental plot was $4.4 \mathrm{hm}^{2}$. The stocking rate in each treatment was 0 (no grazing, CK), 0.91 (light grazing, LG), 1.82 (moderate grazing, MG) and 2.71 (heavy grazing, HG) sheep unit $\cdot\left(\mathrm{hm}^{2} \mathrm{~A}^{-1}\right)^{-1}$. The stocking rates were set according to the results of Wei et al. [29]. In this experiment, 2-year-old adult sheep were selected and allowed to graze from June to November every year. During the experiment, the management measures in each grazing area were the same. The sheep were driven into the grazing area at $6 \mathrm{a} . \mathrm{m}$. and back to the shed at 6 p.m. every day, during which the sheep were free to feed. Water was provided twice a day in the morning and evening, and supplementary salt was regularly available in the form of salt bricks.

\section{Sampling and measurements}

Sampling of the roots and leaves of Stipa breviflora: sampling was conducted on August 10, 2020. A transect was set passing through the center of the study plot, and six sampling points with a spacing of $50 \mathrm{~m}$ were arranged on the transect. Five clumps of plants were randomly selected around each sampling point to dig the plant roots $20 \mathrm{~cm}$ deep underground and loose soil on the surface of the roots was removed, and the rhizosphere soil was obtained by the shaking method. After the aboveground green leaves and roots had been separated, they were immediately put into an ice box, and samples from every three sampling points were combined into one sample. The roots and leaves from each of the 12 treatment plots were sampled with 6 replicates, making a total of 48 samples. Half of the samples were used to determine the activities of nitrogen assimilation related enzymes and nitrogen compounds in roots and leaves. Half of the samples were heated at $105{ }^{\circ} \mathrm{C}$ for $30 \mathrm{~min}$ and then dried at $65{ }^{\circ} \mathrm{C}$ for $24 \mathrm{~h}$ to determine the total nitrogen content. Five replicates of each treatment sample were selected for determination of nitrogen assimilation related enzyme activities and nitrogen compounds. The remaining samples and the remaining set of replicates were stored at $-80{ }^{\circ} \mathrm{C}$ in a refrigerator as a backup. The contents of total nitrogen in rhizosphere soil, plant roots and leaves were determined using an elemental analyzer.

We cleaned the fresh plant leaves and roots repeatedly with distilled water until there is no dirt, and then absorbed the residual distilled water on the surface of the leaves and roots with filter paper. The relevant indicators were determined according to the experimental guidance as follows.

\section{Nitrate nitrogen}

We put $2.00 \mathrm{~g}$ of chopped and mixed plant samples into a test tube, added $10 \mathrm{ml}$ of non-ionic water, 
sealed the tube, and placed it in a boiling water bath for $30 \mathrm{~min}$, filtered the extract into a $25 \mathrm{ml}$ volumetric flask, and fixed the volume to the scale. In a $1 \mathrm{ml}$ sample solution, we added $0.4 \mathrm{ml} 5 \%$ salicylic acid sulfuric acid solution, mixed it well, and left it at room temperature for $20 \mathrm{~min}$, added $9.5 \mathrm{ml} 8 \%$ $\mathrm{NaOH}$ solution, and then measured and record the optical density at $410 \mathrm{~nm}$ wavelength, and calculated the content of nitrate nitrogen [30].

\section{Soluble protein}

$0.5 \mathrm{~g}$ of plant sample was ground and extracted with 5 $\mathrm{ml}$ distilled water. We took $1.0 \mathrm{ml}$ and put it into a tube with a plug, added $5 \mathrm{ml}$ of Coomassie brilliant blue G250 solution, mixed it well, and after 2 min measured and recorded the optical density value at $595 \mathrm{~nm}$ wavelength, and calculated the soluble protein content [30].

\section{Proline}

We put $0.5 \mathrm{~g}$ of chopped and mixed plant sample into a test tube, added $5 \mathrm{ml}$ of $3 \%$ sulfosalicylic acid solution, sealed the test tube, and extracted it in boiling water bath for $10 \mathrm{~min} .2 \mathrm{ml}$ of the extraction solution was put into a test tube, and $2 \mathrm{ml}$ glacial acetic acid and $3 \mathrm{ml}$ chromogenic solution (glacial acetic acid and $6 \mathrm{~mol} \mathrm{~L}^{-1}$ phosphoric acid mixed in 3:2) were added before heating in boiling water bath for $40 \mathrm{~min}$. Then, we added $5 \mathrm{ml}$ toluene for extraction, determined and recorded the absorbance at $520 \mathrm{~nm}$, and calculated the content of proline [30].

\section{Free amino acids}

We took $1.00 \mathrm{~g}$ of plant sample, put it in a mortar, added $5 \mathrm{ml}$ of $10 \%$ acetic acid, ground it thoroughly, transferred it to a $100 \mathrm{ml}$ volumetric flask, fix the volume with distilled water, and filtered it. We put $0.5 \mathrm{ml}$ of sample solution into a $20 \mathrm{ml}$ plug calibration tube, added $0.5 \mathrm{ml}$ of acetic acid cyanate buffer solution and $0.5 \mathrm{ml}$ of $3 \%$ ninhydrin solution, put it in boiling water bath for $12 \mathrm{~min}$, added $5 \mathrm{ml}$ of $95 \%$ ethanol after cooling, and then sealed and shook the tube vigorously, after which we measured and recorded the optical density at $560 \mathrm{~nm}$, and calculated the concentration of free amino acids [30].

\section{Nitrate reductase (NR) activity}

$0.5 \mathrm{~g}$ fresh plant samples were cut up in a mortar and frozen for $30 \mathrm{~min}$ at low temperature. $4 \mathrm{ml}$ buffer solution $(0.1211 \mathrm{~g}$ cysteine, $0.0372 \mathrm{~g}$ EDTA dissolved in 100 $\mathrm{ml} 0.025 \mathrm{~mol} \cdot \mathrm{L}^{-1} \mathrm{pH} 8.7$ phosphate buffer solution) was added to the mortar, and then transferred to a centrifuge tube and centrifuged at $4{ }^{\circ} \mathrm{C} 4000 \mathrm{r} \mathrm{min}^{-1}$ for $15 \mathrm{~min}$. We put $0.4 \mathrm{ml}$ crude enzyme solution in a 10 $\mathrm{ml}$ test tube, added $1.4 \mathrm{ml} 0.1 \mathrm{~mol} \mathrm{~L}^{-1} \mathrm{KNO}_{3}$ phosphate buffer and $0.2 \mathrm{ml} \mathrm{NADH}$ solution, mixed it well, and kept it warm in a water bath at $25{ }^{\circ} \mathrm{C}$ for $30 \mathrm{~min}$, and a control without NADH was replaced with $0.1 \mathrm{~mol} \mathrm{~L}^{-1}$ $\mathrm{pH} 7.5$ phosphate buffer. After heat preservation, we added $1 \mathrm{ml}$ of sulfonamide solution and $1 \mathrm{ml}$ of naphthyl vinylamine solution immediately. After $15 \mathrm{~min}$ of color development and centrifuging at 4000 $\mathrm{min}^{-1}$ for $5 \mathrm{~min}$, we took the supernatant, measured and recorded the optical density at $540 \mathrm{~nm}$ wavelength, and calculated the nitrate reductase activity [30].

\section{Glutamine synthetase (GS) and glutamic acid synthetase (GOGAT)}

We put $1.0 \mathrm{~g}$ of plant material into a mortar, added $6 \mathrm{ml}$ buffer (0.05 mol L ${ }^{-1}$ Tris-HCl buffer, $\left.\mathrm{pH} 8.0\right)$, put it in an ice bath, ground it evenly, transferred it into a centrifuge tube, centrifuged at $4{ }^{\circ} \mathrm{C} 15000 \mathrm{r} \mathrm{min}^{-1}$ for $20 \mathrm{~min}$, and the resulting supernatant was crude enzyme. For GS, we combined $1.6 \mathrm{ml}$ of reaction solution $\mathrm{B}(0.1 \mathrm{~mol}$ $\mathrm{L}^{-1}$ Tris- $\mathrm{HCl}$ buffer, $80 \mathrm{~mol} \mathrm{~L}^{-1}$ hydroxylamine hydrochloride, $\mathrm{pH} 7.4$ ), $0.7 \mathrm{~mL}$ of crude enzyme solution and $0.7 \mathrm{~mL}$ of $50 \mathrm{mmol} \mathrm{L}^{-1}$ ATP solution, mixed it well, kept it at $37{ }^{\circ} \mathrm{C}$ for $0.5 \mathrm{~h}$, added $1 \mathrm{ml}$ of chromogenic agent, centrifuged at 5000r min ${ }^{-1}$ for $10 \mathrm{~min}$, and took the supernatant to determine the absorbance at $540 \mathrm{~nm}$ and recorded it, and using $1.6 \mathrm{ml}$ of mixture A $(0.1 \mathrm{~mol}$ $\mathrm{L}^{-1}$ Tris- $\mathrm{HCl}$ buffer, $\mathrm{pH}$ 7.4) as the control, the activity of glutamine synthetase was calculated according to the difference in absorbance between reaction solution $\mathrm{B}$ and reaction solution A. For GOGAT, the total volume of the reaction was $3 \mathrm{ml}\left(0.4 \mathrm{ml} 20 \mathrm{mmol} \mathrm{L}^{-1} \mathrm{~L}\right.$-glutamine, $0.05 \mathrm{ml} 0.1 \mathrm{M}$ a-ketoglutarate, $0.1 \mathrm{ml} 10 \mathrm{mmol} \mathrm{l-}$ $1 \mathrm{kcl}, 0.2 \mathrm{ml} 3 \mathrm{mmol} \mathrm{L}^{-1} \mathrm{NADH}$, and $0.5 \mathrm{ml}$ enzyme solution), and the insufficient volume was supplemented by $25 \mathrm{mmol} \mathrm{l} \mathrm{L}^{-1} \mathrm{pH} 7.6 \mathrm{Tris} \mathrm{HCl}$ buffer. The reaction was started by L-glutamine, and the change in nitrification value at $340 \mathrm{~nm}$ wavelength was determined. A decrease of 0.001 extinction value per minute was taken as an enzyme activity unit [31, 32].

\section{Glutamic oxaloacetic transaminase (GOT) and glutamic pyruvate transaminase (GPT)}

We put $0.2 \mathrm{~g}$ of the mixed plant material into a mortar, added $2.0 \mathrm{ml}$ buffer solution $\left(0.05 \mathrm{~mol} \mathrm{~L}^{-1}\right.$ Tris- $\mathrm{HCl}$ buffer solution, $\mathrm{pH}$ 7.2), ground it in an ice bath, and the homogenate was centrifuged at 20,000×g for $20 \mathrm{~min}$. The supernatant was crude enzyme solution. For GOT, we took two $10 \mathrm{ml}$ test tubes. One tube was used as the test tube, and we added $0.1 \mathrm{ml}$ of crude enzyme and 0.5 $\mathrm{ml}$ of GOT substrate solution. The other tube was used as the control tube, and we added $0.1 \mathrm{ml}$ of crude enzyme. The two test tubes were placed in $37{ }^{\circ} \mathrm{C}$ water bath for $60 \mathrm{~min}$ at the same time, and then removed. We added $0.5 \mathrm{ml}$ of 2,4-dinitrophenylhydrazine solution 
to each test tube to terminate the reaction. We added $0.5 \mathrm{ml}$ of GOT substrate solution to the control test tube and put the two test tubes in $37{ }^{\circ} \mathrm{C}$ water bath for $20 \mathrm{~min}$, took them out, and then added $0.4 \mathrm{~mol} \mathrm{~L}^{-1}$ $\mathrm{NaOH} 5.0 \mathrm{ml}$ to each tube, mixed them well, then compared the color with $500 \mathrm{~nm}$ wavelength after $10 \mathrm{~min}$, adjusted the zero point with distilled water, and read the absorbance value and calculated the GOT activity. For GPT, we took two $10 \mathrm{ml}$ test tubes. One tube was used as the test tube, and we added $0.1 \mathrm{ml}$ of crude enzyme and $0.5 \mathrm{ml}$ of GPT substrate solution. The other tube was used as the control tube, and we added $0.1 \mathrm{ml}$ of crude enzyme. The two test tubes were placed in $37{ }^{\circ} \mathrm{C}$ water bath for $30 \mathrm{~min}$ at the same time, and then removed. We added $0.5 \mathrm{ml}$ of 2,4-dinitrophenylhydrazine solution to each test tube to terminate the reaction. We added $0.5 \mathrm{ml}$ of GPT substrate solution to the control test tube, and put the two test tubes in $37{ }^{\circ} \mathrm{C}$ water bath for $20 \mathrm{~min}$, removed them, and then added $0.4 \mathrm{~mol} \mathrm{~L}^{-1}$ $\mathrm{NaOH} 5.0 \mathrm{ml}$ to each tube and mixed them well. We compared the color with $500 \mathrm{~nm}$ wavelength after $10 \mathrm{~min}$, adjusted the zero point with distilled water, and read the absorbance value and calculated the GPT activity [33].

\section{Ammonium nitrogen and nitrate nitrogen in rhizosphere soil}

Ammonium nitrogen and nitrate nitrogen content in rhizosphere soil were extracted by potassium chloride and determined by AA3 continuous flow analyzer (AVTO ANACY AA3, German SEAL company).

\section{Nitrogen content in roots and leaves}

The dried plant samples were ground into powder by ball mill, and the nitrogen content in leaves and roots was determined by elemental analyzer (Elementar Vario MACRO CUBE).

\section{Statistical analyses}

One-way ANOVAs with Duncan's test were used to evaluate the difference between the four grazing intensities, and $\mathrm{P}<0.05$ was used to indicate significant difference. We used SPSS25.0 software to calculate Pearson correlation coefficients between variables (correlations between nitrogen content, nitrogen compound content and activities of enzymes related to nitrogen assimilation), * and $* *$ are used to denote significant and extremely significant correlations, respectively (Table 1). Figures 2, 3 and 4 were plotted with Sigma Plot 14.0 software. Taking moderate grazing as the standard, we compared the activities of enzymes related to nitrogen assimilation in plants from no grazing and heavy grazing treatments, and plotted the changes in enzyme activities in the process of nitrogen assimilation with PowerPoint software (Fig. 5).
Table 1 Correlation analysis of nitrogen content, nitrogen compound content and nitrogen assimilation related enzyme activities

\begin{tabular}{llllll}
\hline Indexes & TN & SP & Pro & NN & FAA \\
\hline GOGAT & 0.665 & 0.674 & 0.656 & $0.789^{*}$ & 0.652 \\
GS & $-0.922^{* *}$ & $-0.937^{* *}$ & $-0.744^{*}$ & $-0.816^{*}$ & $-0.891^{* *}$ \\
GOT & $0.996^{* *}$ & $0.994^{* *}$ & 0.688 & $0.871^{* *}$ & $0.961^{* *}$ \\
GPT & $0.978^{* *}$ & $0.975^{* *}$ & 0.66 & $0.856^{* *}$ & $0.945^{* *}$ \\
NR & $0.992^{* *}$ & $0.984^{* *}$ & 0.629 & $0.893^{* *}$ & $0.933^{* *}$ \\
\hline
\end{tabular}

Note: GOGAT, GS, GOT, GPT and NR represent glutamate synthetase, glutamine synthetase, glutamate oxaloacetate transaminase, glutamate pyruvate transaminase and nitrate reductase, respectively. TN, SP, Pro, NN and FAA represent total nitrogen content, soluble protein, proline, nitrate nitrogen and free amino acid, respectively. " $* *$ " indicates significant correlation at 0.01 level and "*" indicates significant correlation at 0.05 level. "-"indicates significant negative correlation at 0.01 or 0.05 level

\section{Results}

The total nitrogen content of the root system of S. breviflora was significantly higher than that under light grazing and moderate grazing, while in the heavy grazing treatment the total nitrogen content in leaves was significantly lower than that under light grazing and moderate grazing (Fig. 2a and b). The results showed that heavy grazing increased the total nitrogen content in the roots and decreased the total nitrogen content in the leaves of $S$. breviflora to a certain extent, especially under heavy grazing. Nitrate reductase plays an important role in the conversion of $\mathrm{NO}_{3}{ }^{-}$to $\mathrm{NH}_{4}{ }^{+}$in plants. The activity of nitrate reductase in roots under heavy grazing was the lowest, which was significantly lower than that under no grazing, while there was no significant difference between light and moderate grazing (Fig. 2c). Compared with light and moderate grazing, no grazing and heavy grazing significantly reduced nitrate reductase activity in leaves of S. breviflora. (Fig. 2d). It shows that light grazing and moderate grazing are conducive to the transformation of $\mathrm{NO}_{3}{ }^{-}$into $\mathrm{NH}_{4}{ }^{+}$in plant roots and leaves.

The nitrogen absorbed and assimilated by plants mainly came from ammonium and nitrate in rhizosphere soil. Our study showed that grazing intensity had a significant effect on the content of ammonium and nitrate in the roots of S. breviflora. With increasing grazing intensity, the content of ammonium nitrogen in the rhizosphere soil of S. breviflora decreased gradually (Fig. 2e). The nitrate content in the rhizosphere soil of $S$. breviflora under moderate and heavy grazing treatments was significantly lower than that under no grazing and light grazing treatments (Fig. 2f).

Nitrogen compounds in plants include soluble proteins and various amino acids. This study shows that grazing has affected the content of nitrogen compounds in plant roots and leaves (Fig. 3). Grazing intensity had a similar effect on the proline content in roots and leaves 

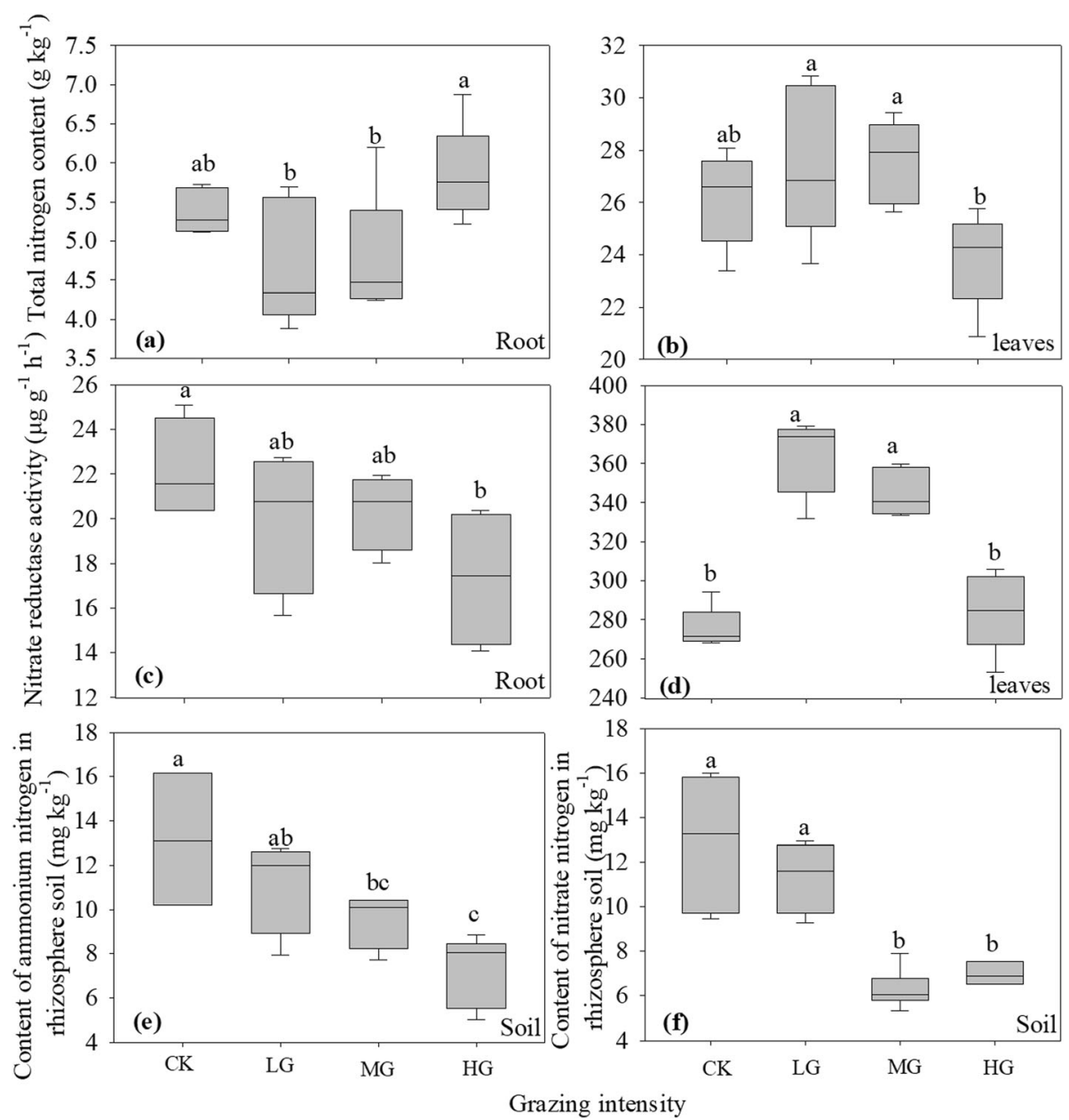

Fig. 2 Effects of grazing intensity on total nitrogen content, nitrate reductase activity in roots and leaves of Stipa breviflora and contents of ammonium nitrogen and nitrate nitrogen content in rhizosphere soil of Stipa breviflora. $\mathbf{a}$ and $\mathbf{b}$ total nitrogen content $\left(\mathrm{g} \mathrm{kg}^{-1}\right)$, $\mathbf{c}$ and $\mathbf{d}$ nitrate reductase activity $\left(\mathrm{\mu g} \mathrm{g}^{-1} \mathrm{~h}^{-1}\right)$, e ammonium nitrogen content $\left(\mathrm{mg} \mathrm{g}^{-1}\right)$, $\mathbf{f}$ nitrate nitrogen content $\left(\mathrm{mg} \mathrm{kg}^{-1}\right)$. Different lowercase letters indicate significant difference at $P<0.05$. CK, LG, MG and $\mathrm{HG}$ refer to no grazing, light grazing, moderate grazing and heavy grazing, respectively

of $S$. breviflora, which decreased first and then increased with increasing grazing intensity (Fig. $3 \mathrm{a}$ and $\mathbf{e}$ ). The proline content was the lowest under moderate grazing, and the highest in the heavy grazing treatment, and the proline content in the heavy grazing treatment was significantly higher than that in no grazing, light and moderate grazing treatments. The content of nitrate nitrogen in the roots and leaves of $S$. breviflora under moderate and heavy grazing was significantly lower than that under light grazing (Fig. $3 \mathrm{~b}$ and d). The content of soluble protein in the roots of S. breviflora under grazing prohibition was significantly higher than that under light, medium and heavy grazing, and the content of soluble protein under light grazing was significantly higher than that under medium and heavy grazing (Fig. 3e). There was no significant difference in soluble protein content of S. breviflora leaves under different grazing treatments (Fig. 3 g). With increasing grazing intensity, the content of free amino acids in the roots of S. breviflora increased at first and then decreased, and was the highest under moderate grazing and the lowest in the no grazing treatment (Fig. 3f). However, free amino acids in leaves first decreased and then increased, and was the lowest under light grazing and the highest under heavy grazing (Fig. $3 \mathrm{~h}$ ).

GS / GOGAT cycle is an important process in plant nitrogen assimilation, in which glutamate synthase and glutamine synthetase catalyze the conversion of $\mathrm{NH}_{4}{ }^{+}$to glutamate and glutamine. The activity of glutamate synthase in roots and leaves of $S$. breviflora under moderate grazing was significantly lower than that under no grazing, light grazing and heavy grazing, and the activity of glutamate synthase in leaves under light and heavy grazing was significantly lower than that under no grazing (Fig. 4a and c). With increasing grazing intensity, the activity of glutamine 


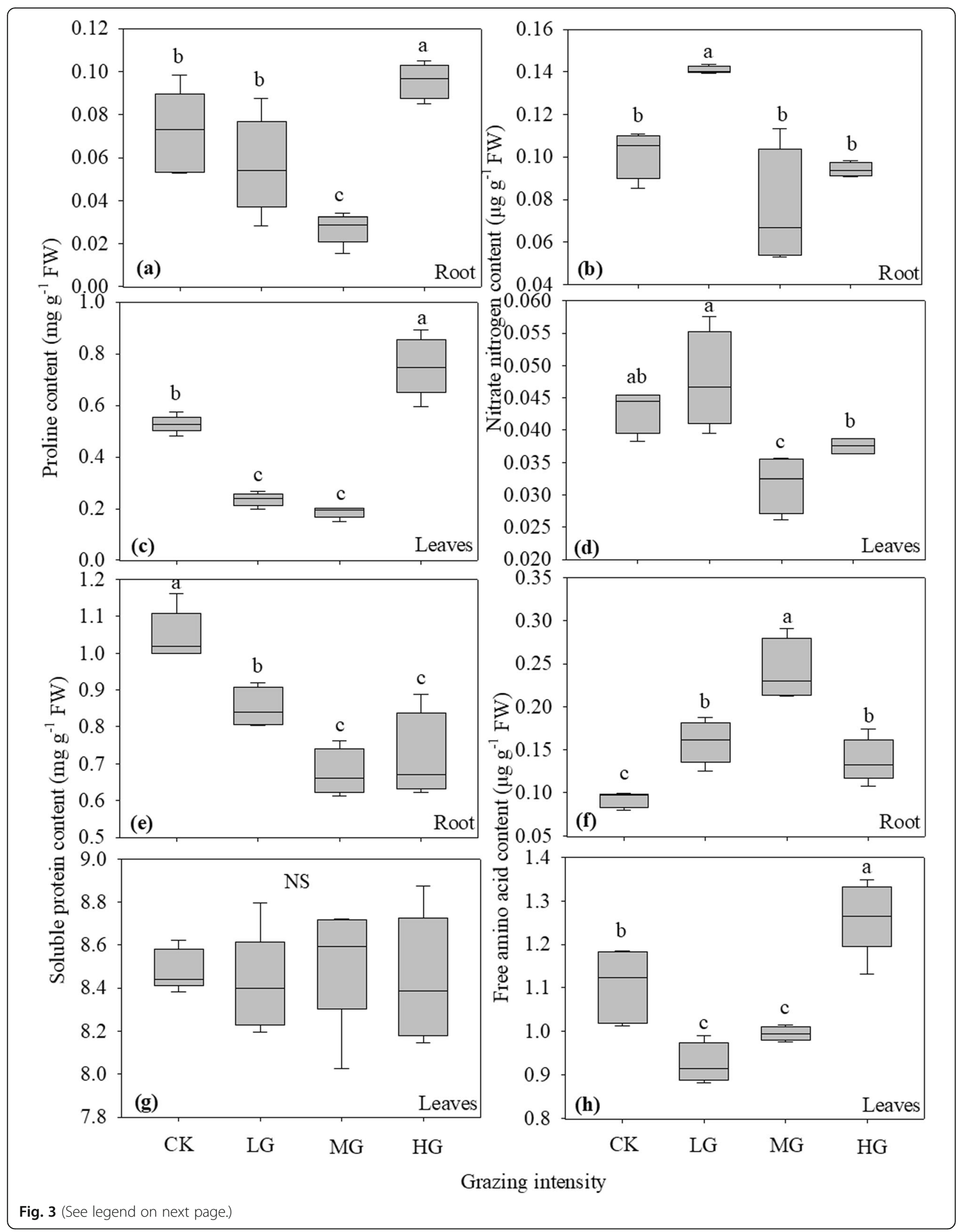


(See figure on previous page.)

Fig. 3 Effects of grazing intensity on nitrogen compounds and nitrate nitrogen contents in roots and leaves of Stipa breviflora. $\mathbf{a}$ and $\mathbf{c}$ proline content ( $\left.\mathrm{mg} \mathrm{g}^{-1} \mathrm{FW}\right), \mathbf{b}$ and $\mathbf{d}$ nitrate nitrogen contents ( $\mu \mathrm{g} \mathrm{g}{ }^{-1} \mathrm{FW}$ ), e and $\mathbf{g}$ soluble protein content ( $\mathrm{mg} \mathrm{g}^{-1} \mathrm{FW}$ ), $\mathbf{f}$ and $\mathbf{h}$ free amino acid content $\left(\mu \mathrm{g} \mathrm{g}^{-1} \mathrm{FW}\right.$ ). Different lowercase letters indicate significant difference at $P<0.05$. "Ns" in the figure indicates that there is no significant difference among grazing treatments. CK, LG, MG and HG refer to no grazing, light grazing, moderate grazing and heavy grazing, respectively

synthetase in roots and leaves of S. breviflora first increased and then decreased (Fig. 4b and d).

Glutamic oxaloacetic transaminase and glutamate pyruvate transaminase play an important role in catalyzing the conversion of glutamate and glutamine to aspartic and asparagines. The effects of grazing intensity on the activity of glutamic oxaloacetic transaminase in the roots and leaves of $S$. breviflora differed. The activity of glutamic oxaloacetic transaminase in the roots of $S$. breviflora under heavy grazing was significantly higher than that under no grazing, while the activity of glutamic oxaloacetic transaminase in the leaves of S. breviflora under light and moderate grazing was significantly higher than that under no grazing and heavy grazing (Fig. 4e and g). Grazing had the same effect on the activity of glutamate pyruvate transaminase in the roots and leaves of S. breviflora. There was no significant difference among light, moderate and heavy grazing, but they were significantly higher than in the no grazing treatment (Fig. $4 \mathrm{f}$ and $\mathbf{h}$ ).

According to Table 1, the activities of glutamine synthetase, glutamic oxaloacetic transaminase and glutamic pyruvate transaminase were significantly negatively correlated with the total nitrogen content in roots and leaves, while the activities of nitrate reductase, glutamic oxaloacetic transaminase and glutamic pyruvate transaminase were significantly positively correlated with total nitrogen content. The content of soluble protein was positively correlated with the activities of glutamine synthetase, nitrate reductase, glutamic oxaloacetate transaminase and pyruvate transaminase. Nitrate nitrogen content in roots and leaves was significantly positively correlated with glutamate synthetase activity, while nitrate nitrogen and free amino acid content were significantly negatively correlated with glutamine synthetase activity. The contents of nitrate nitrogen and free amino acids were positively correlated with the activities of nitrate reductase, glutamic oxaloacetic transaminase and glutamic pyruvate transaminase.

Taking moderate grazing as the standard, we compared the activities of enzymes related to nitrogen assimilation in plants from no grazing and heavy grazing treatments. The activities of enzymes related to nitrogen assimilation in roots and leaves of S. breviflora changed to different degrees under grazing exclusion and heavy grazing (Fig. 5). Although the content of nitrate and ammonium nitrogen in the rhizosphere soil of S. breviflora was high under grazing exclusion, the activities of nitrate reductase, glutamine synthetase, glutamic oxaloacetic transaminase and glutamic pyruvate transaminase in leaves of S. breviflora under grazing exclusion were low, and the activities of glutamine synthetase, glutamic oxaloacetic transaminase and glutamic pyruvate transaminase in roots of $S$. breviflora under grazing exclusion were low. Heavy grazing decreased the activities of nitrate reductase, glutamine synthetase and glutamic pyruvate transaminase in leaves of $S$. breviflora, and the activities of glutamine synthetase in roots of $S$. breviflora.

\section{Discussion}

Grazing is one of the most important management practices in desert steppe, but its fragile ecological characteristics make soil and vegetation extremely sensitive to the disturbance of grazing livestock [8, 34]. Significant amounts of energy and material are removed by grazing disturbance, especially in heavily and overgrazed grassland $[35,36]$. The absorption and utilization efficiency of plant nutrients can reflect the growth state and internal characteristics of plants. In low productivity ecosystems, grazing results in a decrease in soil nitrogen pools [37, 38]. In this study, the hypothesis that grazing intensity affects the activities of nitrogen assimilation related enzymes in plant roots and leaves was supported, and the results showed that changes in nitrogen assimilation related enzyme activities affect the nitrogen absorption and utilization efficiency of plants. This can be seen from the changes in total nitrogen content and nitrate nitrogen content in roots and leaves of S. breviflora. Different from our first hypothesis, not all the changes in enzyme activities related to nitrogen assimilation were consistent with the moderate interference hypothesis.

Nitrogen assimilation plays a crucial role in plant life activities, and directly affects the growth and development of plants [39]. Nitrate reductase (NR), glutamine synthetase (GS), glutamic acid synthetase (GOGAT), glutamic oxaloacetate transaminase (Got) and glutamic pyruvate transaminase (GPT) activities directly affect the nitrogen assimilation process of plants, and also affects the assimilation efficiency of nitrogen [40]. According to the correlation analysis results on total nitrogen content, nitrogen compound content and nitrogen assimilation related enzyme activities in the roots and leaves of $S$. breviflora (Table 1), our hypothesis that nitrogen content and nitrogen compound content in the leaves and roots of $S$. breviflora would be closely related to nitrogen assimilation related enzyme activities was generally 


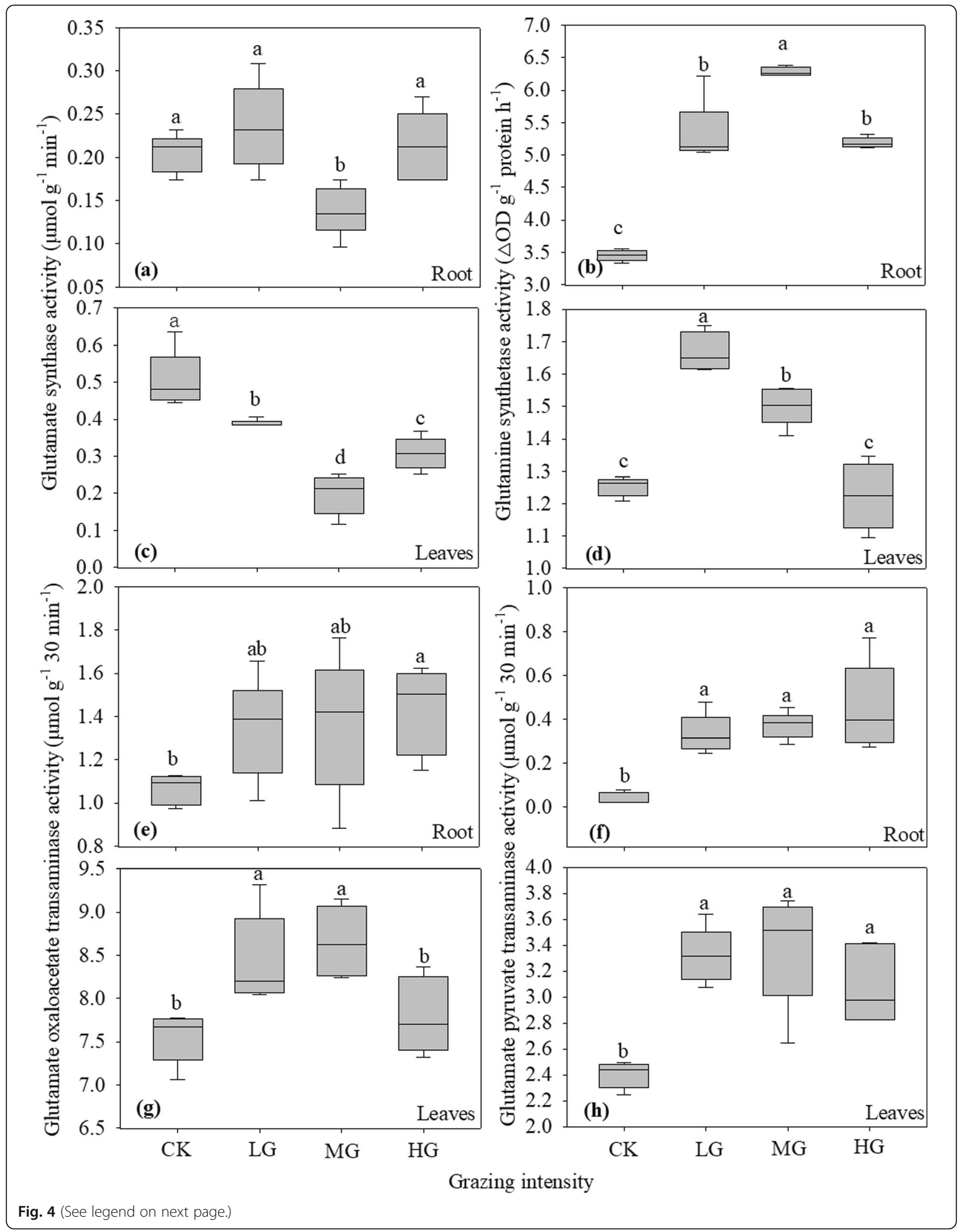


(See figure on previous page.)

Fig. 4 Effects of grazing intensity on activities of nitrogen assimilation related enzymes in roots and leaves of Stipa breviflora. a and c glutamate synthase activity $\left(\mu \mathrm{mol} \mathrm{g} \mathrm{g}^{-1} \mathrm{~min}^{-1}\right), \mathbf{b}$ and $\mathbf{d}$ glutamine synthetase activity $\left(\triangle \mathrm{OD} \mathrm{g}{ }^{-1}\right.$ protein $\left.\mathrm{h}^{-1}\right)$, e and $\mathbf{g}$ glutamic oxaloacetic transaminase activity ( $\left.\mu \mathrm{mol} \mathrm{g}{ }^{-1} 30 \mathrm{~min}^{-1}\right)$, $\mathbf{f}$ and $\mathbf{h}$ glutamate pyruvate transaminase activity ( $\mu \mathrm{mol} \mathrm{g}{ }^{-1} 30 \mathrm{~min}^{-1}$ ). Different lowercase letters indicate significant difference at $P<0.05$. CK, LG, MG and HG refer to no grazing, light grazing, moderate grazing and heavy grazing, respectively

supported, but not all the activities of nitrogen assimilation related enzymes were significantly positively correlated with the content of nitrogen compounds, which was different from the findings of previous studies [34, 41]. Because there are few studies on the activities of enzymes related to plant nitrogen assimilation in grassland, we have not even found relevant research reports, so here we further discuss and analyze the role of related enzymes in the process of plant nitrogen assimilation.
NR is a key enzyme in the process of nitrogen metabolism, and its activity is closely related to nitrogen assimilation capacity [42]. Part of the $\mathrm{NO}_{3}{ }^{-}$absorbed by plant roots generates $\mathrm{NH}_{4}{ }^{+}$under the catalysis of $\mathrm{NR}$ and $\mathrm{NiR}$, and the other part is transferred to the leaves. Our results indicated that the heavy grazing treatment significantly reduced the transformation of $\mathrm{NO}_{3}{ }^{-}$to $\mathrm{NH}_{4}{ }^{+}$in the root system of S. breviflora, and the conversion of $\mathrm{NO}_{3}{ }^{-}$to $\mathrm{NH}_{4}{ }^{+}$in leaves was significantly reduced

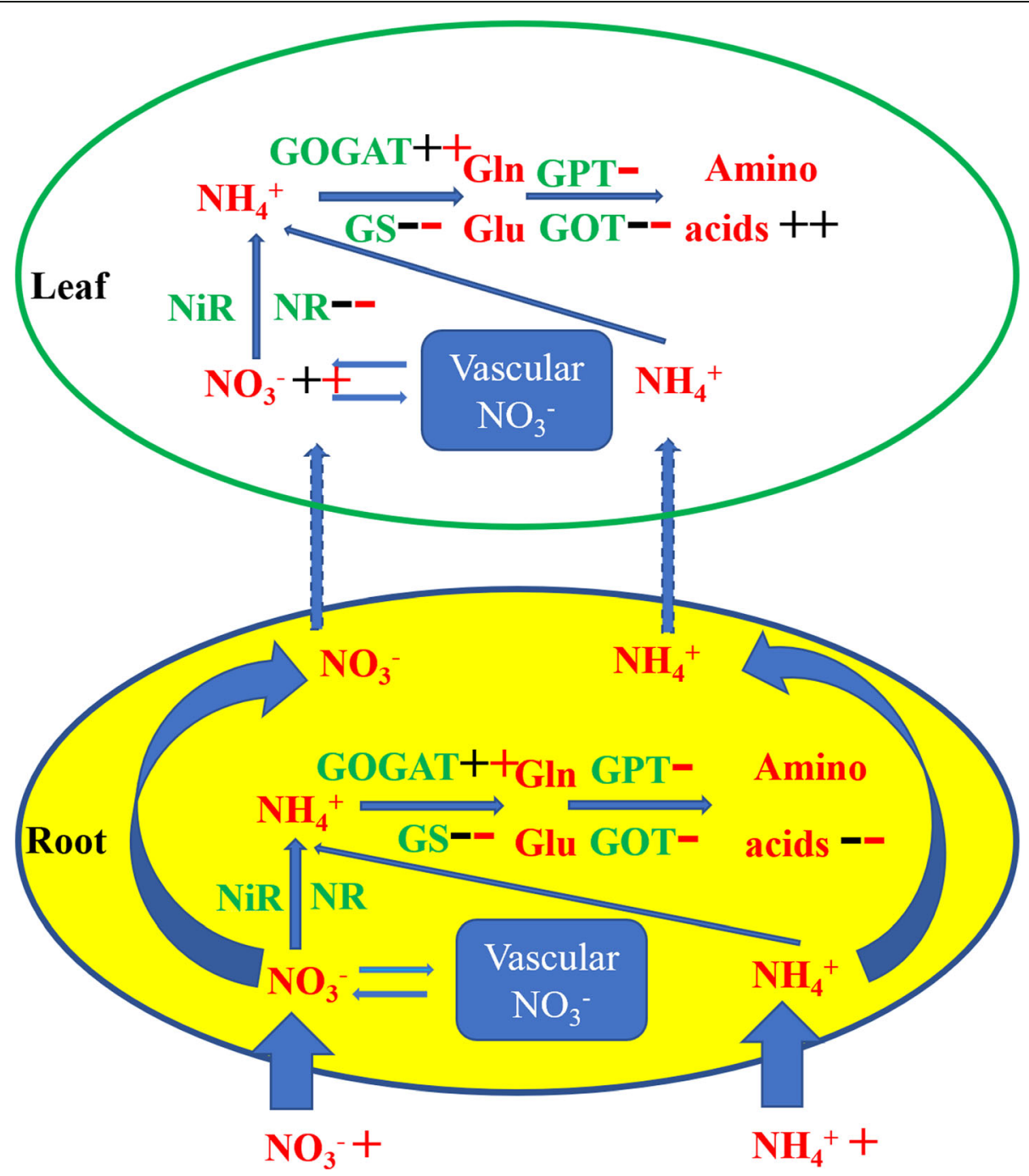

Fig. 5 Effects of heavy grazing and no grazing on nitrogen absorption and assimilation pathways in roots and leaves of S. breviflora. The black "+" and "-" in the figure represent the significant positive and negative effects of heavy grazing on the index compared with moderate grazing, and the red "+" and "-" represent the significant positive and negative effects of no grazing on the index compared with moderate grazing. NR: nitrate reductase; NiR: nitrite reductase; GS: glutamine synthetase; GOGAT: glutamic acid synthetase; GOT: Glutamic oxaloacetic transaminase; GPT: glutamic pyruvate transaminase; Glu: glutamate; Gln: glutamine 
by grazing exclusion and heavy grazing, which affected the efficiency of nitrogen assimilation. A deficiency of this study is that it did not measure $\mathrm{NH}_{4}{ }^{+}$and $\mathrm{NiR}$ in the roots and leaves of $S$. breviflora. Light and moderate grazing significantly increased NR activity in leaves, and it is inferred that the conversion efficiency of $\mathrm{NO}_{3}{ }^{-}$to $\mathrm{NH}_{4}{ }^{+}$is high, which may also be the reason for the high nitrogen content in S. breviflora leaves under light and moderate grazing.

Under the catalysis of GS and GOGAT, $\mathrm{NH}_{4}{ }^{+}$forms glutamic acid and glutamine, and GS and GOGAT process are carried out simultaneously. Li et al. [34] studied the process of nitrogen assimilation in maize, and showed that the higher the activity of GS and GOGAT, the stronger the ability for nitrogen assimilation. Our research showed slightly different results in that there was a significant negative correlation between GS and total nitrogen content in roots and leaves of $S$. breviflora. That is, the higher the GS activity in roots and leaves, the lower the total nitrogen content in roots and leaves of S. breviflora. However, this finding is similar to the results of Fei et al. [43], who showed that GS activity did not follow the same trend as biomass and nutrient content. The reason may be related to the content of $\mathrm{NH}_{4}{ }^{+}$in plant roots and leaves, because studies have shown that GS is more sensitive to low concentrations of $\mathrm{NH}_{4}^{+1}$, and GS activity will be significantly reduced under high $\mathrm{NH}_{4}{ }^{+}$[44]. In our study, there was a significant positive correlation between GOGAT activity and total nitrogen content in roots and leaves, which was the same as found in previous studies [41]. GOT and GPT are important transaminases in the process of nitrogen assimilation in plant roots and leaves. Wang et al. [34] showed that GOT and GPT activities were significantly positively correlated with total nitrogen content in leaves of plants, and our study found the same result, indicating that the higher GOT and GPT activities in roots and leaves of S. breviflora, the higher total nitrogen content. These results indicate that under light and moderate grazing disturbance, grassland plants can improve their nitrogen assimilation and utilization efficiency by regulating the increase of some nitrogen assimilation related enzyme activities (NR, GS, GOT and GPT).

The process of nitrogen assimilation in plants is complex, not only involving many enzymes, but also the amount of substrate produced affects the assimilation efficiency [44]. Our results showed that heavy grazing significantly reduced the content of soluble protein and amino acids in roots, and significantly increased the content of amino acids in leaves, and correlation analysis showed that this was related to the changes in GS, GOT, GPT and NR activities in roots and leaves. Therefore, we suggest that grazing exclusion and heavy grazing significantly affect the formation of substrate in the process of nitrogen assimilation. The content of proline could reflect the stress intensity of plants to a certain extent $[45,46]$. Grazing can disturb the growth state and adaptability of plants, so it has been considered as a biological stress for most plant species [12]. Therefore, in our study, the higher proline content in roots and leaves of $S$. breviflora under grazing prohibition and heavy grazing showed that grazing prohibition and heavy grazing were not conducive to the normal growth and development of plants.

In addition to the change in enzyme activities related to nitrogen assimilation, the change in soil nitrogen content is also an important reason for the influence of grazing intensity on plant nitrogen absorption, as it particularly affects the content of ammonium nitrogen and nitrate nitrogen in rhizosphere soil. Our results differ from those of many studies which have shown that with increasing grazing intensity, the nitrogen content in soil increases gradually due to increased feces and urine deposition by livestock [47, 48]. We suggest that the reason for this difference is due to the different grazing methods. In this experiment, the livestock were fed in the experimental plot during the day, and were driven back to the shed at night to rest, and most of the feces and urine of livestock were left in the shed [21]. The experimental design of other studies has been that livestock feed and rest from morning to night in the experimental area, and livestock excreta are distributed in the experimental area, so the soil nitrogen content was relatively high. Based on the analysis of nitrogen assimilation related enzyme activities and nitrogen compound contents, we concluded that high nitrogen (no grazing) and low nitrogen (heavy grazing) environments were not conducive to nitrogen absorption and utilization in the roots and leaves of $S$. breviflora. Our study only systematically sampled, measured and analyzed $S$. breviflora, a constructive species in the desert grassland. We will further study the nitrogen assimilation mechanism of other plants in the desert grassland, so as to reveal the mechanism of plant nitrogen material cycle in grazing grassland.

\section{Conclusions}

Our results showed that grazing disturbance can change the nitrogen use efficiency of grassland plants by regulating the activities of nitrogen assimilation related enzymes in leaves and roots. Light or moderate grazing disturbance is beneficial to the nitrogen assimilation of grassland plants, and can promote nitrogen cycling in the grassland ecosystem, which is consistent with the moderate disturbance hypothesis. These findings, 
combined with the reported moderate grazing disturbance, are conducive to the improvement of grassland vegetation diversity and productivity, indicating that the appropriate stocking rate plays an important role in the stability and sustainable utilization of the grassland ecosystem.

\begin{abstract}
Abbreviations
CK: No grazing; LG: Light grazing; MG: Moderate grazing; HG: Heavy grazing; NR: Nitrate reductase; GS: Glutamine synthetase; GOGAT: Glutamic acid synthetase; GOT: Glutamic oxaloacetic transaminase; GPT: Glutamic pyruvate transaminase; TN: Total nitrogen content; SP: Soluble protein; Pro: Proline; NN: Nitrate nitrogen; FAA: Free amino acid; Glu: Glutamate; Gln: Glutamine; Asp: Aspartic; Asn: Asparagines
\end{abstract}

\section{Acknowledgements}

Not applicable.

\section{Authors' contributions}

AMZ was responsible for writing the manuscript; GDH was responsible for the design and management of the experiment. HLL, YHW, assisted AMZ in sampling and determination of physiological and biochemical indexes. HLS provided us with grazing grassland. All authors have read and approved the manuscript.

\section{Funding}

This work was supported by the National Natural Science Foundation of China (31760146), Innovative team on Grassland Resources of the Ministry of Education (IRT-17R59), Inner Mongolian Committee of Science and Technology Projects (zdzx2018020, 2019CG069, 2021BS03006). The funding bodies had no role in the design of the study and collection, analysis, and interpretation of data or in writing the manuscript.

\section{Availability of data and materials}

The datasets used and/or analyzed during the current study are available from the corresponding author on reasonable request.

\section{Declarations}

\section{Ethics approval and consent to participate}

The plant sample of Stipa breviflora collected by us is not an endangered species, and has been approved by director Sun Hailian, head of the Research Base of Academy of Agriculture and Animal Husbandry of Inner Mongoloia, who is also one of our co-authors. This sample collection complies with relevant institutional, national, and international guidelines and legislation

\section{Consent for publication}

Not applicable.

\section{Competing interests}

All authors declare that they have no competing interests.

\section{Author details}

${ }^{1}$ College of Grassland, Resources and Environment, Key Laboratory of Grassland Resources of the Ministry of Education of Chian, Key Laboratory of Forage Cultivation, Processing and Higher Efficient Utilization of the Ministry of Agriculture and Rural Affaires of China, Inner Mongolia Key Laboratory of Grassland Management and Utilization, Inner Mongolia Agricultural University, 010019 Hohhot, China. ${ }^{2}$ Research Base of Academy of Agriculture and Animal Husbandry of Inner Mongoloia, 010031 Hohhot, China.

Received: 18 May 2021 Accepted: 1 September 2021

Published online: 25 September 2021

\section{References}

1. Klein JA, Harte J, Zhao XQ. Experimental warming, not grazing, decreases rangeland quality on the Tibetan Plateau. Ecol Appl. 2007;17:541-57.

2. Zheng SX, Lan ZC, Li WH, Shao RX, Shan YM, Wan HW, Taube F, Bai YF. Differential responses of plant functional trait to grazing between two contrasting dominant C3 and C4 species in a typical steppe of Inner Mongolia, China. Plant Soil. 2011;340:141-55.

3. Tóth $E$, Deák $B$, Valkó $O$, Kelemen A, Miglécz T, Tóthmérész B, Török $P$. Livestock type is more crucial than grazing intensity: traditional cattle and sheep grazing in short-grass steppes. Land Degrad Dev. 2018;29: 231-9.

4. Wang $X$, Yan Y, Cao Y. Impact of historic grazing on steppe soils on the northern Tibetan Plateau. Plant Soil. 2012;354:173-83.

5. Zheng S, Ren H, Li W, Lan Z. Scale-dependent effects of grazing on plant C: $\mathrm{N}: \mathrm{P}$ stoichiometry and linkages to ecosystem functioning in the Inner Mongolia grassland. PLoS One. 2012;7.

6. Travers SK, Eldridge DJ, Val J, Oliver I. Rabbits and livestock grazing alter the structure and composition of mid-storey plants in a wooded dryland. Agric., Ecosyst. Environ., 2019;277,53-60.

7. Xiong M, Qiao JR, Yang Y, Zhang F, Zheng JH,Wu JX,Zhao ML. Stocking rate effects on stoichiometric characteristics of the steppe grassland pioneer species Stipa breviflora and its underlying soil. Acta Prataculturae Sinica. 2021:30(2):212-9.

8. Han MQ, Wang ZW, Jin YX,Kang J, Li JW, Wang YH, Wang SX. Response of species diversity and productivity to long-term grazing in the Stipa breviflora desert steppe. Acta Botanica Boreali-Occidentalia Sinica. 2017: 37(11):2273-81

9. Kotanen PM, Rosenthal JP. Tolerating herbivory: does the plant care if the herbivore has a backbone? Evol. Ecol., 2000;14,537 - 49.

10. Wang SP, Duan JC, Xu G P, Wang Y F, Zhang Z, Rui YC, Luo CY, Xu $B$, Zhu XX, Chang XF. Effects of warming and grazing on soil $N$ availability, species composition, and ANPP in an alpine meadow. Ecology, 2012;93:2365-76.

11. Sun Y, Schleuss PM, Pausch J, Xu X, Kuzyakov Y. Nitrogen pools and cycles in Tibetan Kobresia pastures depending on grazing. Biol. Fert. Soils 2018; $54,569-81$

12. Shen H, Dong S, Li S, Dong SK, Li S, Xiao JN, Han YH, Yang MY, Zhang J, Gao XX, Xu YD, Li Y, Zhi YL, Liu SL, Dong QM, Zhou HK, Yeomans JC. Grazing enhances plant photosynthetic capacity by altering soil nitrogen in alpine grasslands on the Qinghai-Tibetan plateau. Agriculture Ecosystems \& Environment. 2019:280:161-8.

13. Meyer C, Stitt M. Nitrate reductase and signalling. In: Lea PJ, Morot-Gaudry JF, editors. Plant nitrogen. New York: Springer; 2001. p. 37-59.

14. Lea P, Miflin B. Alternative route for nitrogen assimilation in higher plants. Nature. 1974;251:614-6.

15. Lea PJ, Forde BG. The use of mutants and transgenic plants to study amino acid metabolism. Plant, Cell and Environment. 1994;17:541-56.

16. Matsumoto S, Noriharu A, Yamagata M. Possible direct uptake of organic nitrogen from soil by chingensai (Brassica campestris L.) and carrot (Daucus carota L.). Soil Biol Biochem. 2000;32:1301-10.

17. Xu X, Ouyang H, Cao G, Pei Z, Zhou C. Uptake of organic nitrogen by eight dominant plant species in Kobresia meadows. Nutr Cycl Agroecosyst. 2004; 69:5-10.

18. Ward $\mathrm{M}$, Grimes $\mathrm{H}$, Huffaker R. Latent nitrate reductase activity is associated with the plasma membrane of corn roots. Planta. 1989;177:470-5.

19. Corsetti Purcino AA, Carvalho Alves VM, Parentoni SN, Luiza Belele C, Loguercio LL. Aluminum Effects on Nitrogen Uptake and Nitrogen Assimilating Enzymes in Maize Genotypes with Contrasting Tolerance to Aluminum Toxicity. Journal of Plant Nutrition. 2003;26(1):31-61.

20. Kaur B, Asthir B, Bains NS. Enzymatic Efficiency and Genotypic Differences for Nitrogen Assimilation in Wheat. Proceedings of the National Academy of Sciences, India - Section B: Biological Sciences, 2015;87(3):1-11.

21. Sun SX, Yun XJ, Wu XH, Wei ZJ, Jiang C, Liu WT. Seasonal variations of ecological stoichiometry characteristics of major plant populations in desert steppe. Ecology and Environmental Sciences, 2018;27(1):47-54.

22. Bai YF, Wu JG, Clark CM, Pan QG, Zhang LX, Chen SP, Wang QB, Han XG Grazing alters ecosystem functioning and C:N:P stoichiometry of grasslands along a regional precipitation gradient. Journal of Applied Ecology. 2012; 49(6):1204-15.

23. An Y, An H, Li SB. Effects of grazing on ecological stoichiometry of soil and dominant plants in desert grassland. Acta Prataculturae Sinica. 2018;27(12): 94-102.

24. Li JW, Wang ZW, Ren HY, Jin YX, Han MQ, Wang SX, Han GD. Plastic response of individual functional traits in Stipa breviflora to long-term grazing in a desert steppe. Acta Bot Boreal Occident Sin. 2017;37(9):185463. 
25. Smith SE. Variation in response to defoliation between populations of Bouteloua curtipendula var. Caespitosa (poaceae) with different livestock grazing histories. American Journal of Botany. 1998;85(9):1266-72.

26. Li $X L$, Hou XY, Wu XH, Sa RL, Ji L, Chen HJ, Liu ZY, Di Y. Plastic response of stem and leaf functional traits in Leymus chinensis to long-term grazing in a meadow steppe. Chinese Journal of Plant Ecology. 2014;38(5):440-51.

27. Wang KB, Shangguan ZP. Seasonal variations in leaf N, and P stoichiometry of typical plants in the Yangou watershed in the loess hilly gully region. Acta Ecologica Sinica. 2011;31(17):4985-91.

28. Niu K, He J, Zhang S, He JS, Zhang ST, Lechowicz MJ. Tradeoffs between forage quality and soil fertility: Lessons from Himalayan rangelands. Agriculture, Ecosystems Environment. 2016;234:31-9.

29. Wei ZJ, Han GD, Yang J, Lu X. The response of Stipa breviflora community to stocking rate. Grassland of China. 2000;6:1-5.

30. Zou Q. Experimental Instruction in Plant Phyiology. Beijing: China Agriculture Publishing House, 2000;34-90.

31. Jin ZX, Qian CR, Yang J, Liu HY. Changes of activity of glutamine synthetase during grain filling and its influence on rice grain quality. Chinese J Rice Sci, 2007;21(1):103-06.

32. Zhao P, He JG, Xiong SP, Ma XM. Studies on the effects of different nitrogen forms on enzyme activity in flag leaves in wheat and protein and yield of grain for specialized end-uses. Journal of China Agricultural University, 2010; 15(3):29-34

33. Wu LH, Jiang $\mathrm{SH}, \mathrm{Tao} \mathrm{QN}$. Colorimetric determination of glutamate oxaloacetate transaminase (GOT) and glutamate pyruvate transaminase (GPT) activity in plants and its application. Chinese Journal of Soil Science, 1998:3:41-3

34. Li WL, Lv XM, Tong T, Tong T, Cao XB, Gu WR, Cao S. Effects of nitrogen fertilizer on nitrogen metabolism enzymes, nitrogen use and yield of maize with different nitrogen efficiency. Southwest China, Journal of Ayicultural Sciences, 2018;31(09):1829-35.

35. Belsky AJ. Regeneration of artificial disturbance in grasslands of the Serengeti National Park, Tanzania. II. Five years of successional change. Journal of Ecology, 1986;74(4):937-51.

36. Acker SA. Vegetation as a component of a non-nested hierarchy: A conceptual model. Journal of Vegetation Science, 1990;1(5):683-90.

37. Holst J, Liu CY, Bruggemann N, Butterbach-Bahl K, Zheng XH, Wang YS, Han $\mathrm{SH}$, Yao ZS, Yue J, Han XG. Microbial N turnover and N-oxide $\left(\mathrm{N}_{2} \mathrm{O} / \mathrm{NO} / \mathrm{NO}_{2}\right)$ fluxes in semi-arid grassland of Inner Mongolia. Ecosystems, 2007;10: 623-34.

38. Hafner S, Unteregelsbacher S, Seeber E, Lena B, Xu X, Li X, Guggenberger G, Miehe $G$, Kuzyakov $Y$. Effect of grazing on carbon stocks and assimilate partitioning in a Tibetan montanepasture revealed by $13 \mathrm{CO}_{2}$ pulse labeling. Glob Chang Biol, 2012;18:528-38.

39. Ge JZ, Li SY, Zhong XY, Yuan GY, Xu Y, Tian SY, Cao CG, Zhai ZB, Liu SQ, Zhan $M$, Zhao M. Effects of nitrogen application and film mulching on yield performance parameters and nitrogen use efficiency of spring maize in the middle reaches of yangtze river. Acta Agronomica Sinica, 2014;40(6):1081092.

40. Yu HR, Guo Y, Zhu AM, Lu FY, Wang L, Zhang YX. Effects of nitrogen fertilizer level on non-structural carbon and nitrogen metabolite levels in oats grown in sandy desert soil. Acta Prataculturae Sinica, 2018;27(5):61-72

41. Wang X, Zhang YX, Bao QL, Chen WD, Sun MX, Guo Y, Yang SK, Luo $Y L$. Effects of nitrogen application rate at seedling stage on the enzyme activities related to nitrogen metabolism in different forage oat varieties. Journal of Inner Mongolia University for Nationalities, 2020;35(05):396-401.

42. Zhang ZM, Wan SB, Ning TY, Dai LX. Effects of nitrogen level on nitrogen metabolism and correlating enzyme activity in peanut. Journal of Plant Ecology, 2008;32(6):1407-16.

43. Fei H, Chaillou S, Hirel B, Chaillou S, Hirel B, Mahon JD, Vessey JK. Overexpression of a soybean cytosolic glutamine synthetase gene linked to organ-specific promoters in pea plants grown in different concentrations of nitrate. Planta, 2003;216:467-74.

44. Zhang $\mathrm{HZ}$, Xu HY. Research progress on the enzymes during plant nitrogen assimilation. Northern Horticulture. 2011;20:180-3.

45. Ibarra-Caballero J, Villanueva-Verduzco C, Molina-Galán J, Sánchez-DeJiménez E. Proline accumulation as a symptom of drought stress in Maize: a tissue differentiation requirement. Journal of Experiments Botany, 1988:39: 889-97.
46. Rasluni P, Agarwal RM, Jeevaratnam K, Sharma GL. Osmotic Stress induced alterations in rice (Oryza Sativa L.) and Recovery on Stress Release. Plant Growth Regul, 2004;42:79-87.

47. Whitehead DC. Nutrient Elements in Grassland: Soil-Plant-Animal Relationships. CABI Publishing. 2002.

48. Zaman M, Saggar S, Blennerhassett JD, Singh J. Effect of urease and nitrification inhibitors on $\mathrm{N}$ transformation, gaseous emissions of ammonia and nitrous oxide, pasture yield and $\mathrm{N}$ uptake in grazed pasture system. Soil Biol. Biochem, 2009;41,1270-80.

\section{Publisher's Note}

Springer Nature remains neutral with regard to jurisdictional claims in published maps and institutional affiliations.

\section{Ready to submit your research? Choose BMC and benefit from:}

- fast, convenient online submission

- thorough peer review by experienced researchers in your field

- rapid publication on acceptance

- support for research data, including large and complex data types

- gold Open Access which fosters wider collaboration and increased citations

- maximum visibility for your research: over $100 \mathrm{M}$ website views per year

At BMC, research is always in progress.

Learn more biomedcentral.com/submissions 